\title{
A FIELD AND NUMERICAL STUDY INTO RIP CURRENTS IN WIND-SEA DOMINATED ENVIRONMENTS
}

\author{
Gundula Winter ${ }^{1}$, Ap van Dongeren ${ }^{1}$, Matthieu de Schipper ${ }^{2}$ and Jaap van Thiel de Vries ${ }^{1,2}$ \\ Rip currents are wave-induced and off-shore directed flows which occur frequently in the surf zone and can pose a \\ serious threat to swimmers. While the behaviour of rip currents has been studied in swell-dominated environments, \\ less is known about their characteristics in wind-sea dominated environments. This study aims to improve the \\ knowledge on rip currents in these environments such as the Dutch coast. In a field campaign at Egmond aan Zee \\ (The Netherlands), Lagrangian velocities in the surf zone were measured with drifter floats. An extensive dataset of \\ rip current measurements was collected from which parameters that initiate rip currents and affect their mean flow \\ properties were identified. Numerical simulations with XBeach aided to understand and confirm the observations \\ made in the field. A reduction of the hydrodynamic parameters along with simplification of the bathymetry in the \\ model allowed for identification of the governing rip current parameters, which can be the basis for a warning system.
}

Keywords: rip currents, field observations, Lagrangian measurements, XBeach

\section{INTRODUCTION}

Rip currents are narrow seaward-directed flows (Bowen, 1969) and pose a serious threat to swimmers at many beaches all over the world. These seaward-directed currents typically pull swimmers offshore whilst the swimmers intuitively try to swim against the current, become exhausted and ultimately require professional help. Brander and MacMahan (2011) estimate that the annual number of drownings associated with rip currents is likely to exceed 500 worldwide. This issue has received attention particularly on swell dominated coasts (Austin et al., 2009; Brander and Short, 2000; Bruneau et al., 2009; MacMahan et al., 2005) where numerous field studies have been undertaken. However, the threat of rip currents is less recognised on wind-sea dominated coasts such as the North Sea, even though a consistent number of swimmers are pulled offshore in rip currents and require rescue by surf lifeguards each year (for example at the study site Egmond aan Zee, The Netherlands).

Although there is a number of mechanisms which generate rip currents (Dalrymple et al., 2011), the present paper focuses on bathymetrically controlled rip currents, in particular flow patterns found on barred coastlines which characterise large parts of the Dutch coast. Here, rip currents are generated when waves break over the bar and exert a force on the water column (Longuet-Higgins and Stewart, 1964). This force causes a relatively high water level set-up in the trough between the beach and the bar whereas the waves break closer to shore and induce less set up (due to the deeper water) in the channel (Figure 1). The resultant alongshore water level gradient initiates a longshore flow parallel to the beach that is referred to as feeder current. The feeder currents converge onshore of the rip channel into an offshore flow, the so-called rip neck. Outside the surf zone the rip current diffuses in the rip head. Together with the onshore mass transport over the sand bar the rip current system fulfils the requirements of mass continuity.

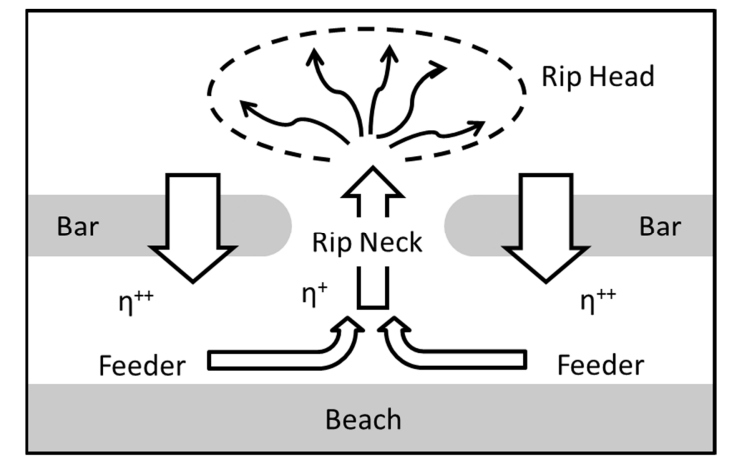

Figure 1 Schematic rip current on a barred coastline. $\eta^{+}$indicates low or no water level set up and $\eta^{++}$ indicates high water level set up.

\footnotetext{
${ }^{1}$ Marine and Coastal Systems, Deltares, P.O. Box 177, 2600 MH Delft, The Netherlands

2 Faculty of Civil Engineering and Geosciences, Delft University of Technology, Postbus 5048, 2600 GA Delft, The Netherlands
} 
A number of field experiments have been undertaken to measure rip currents in the field with fixed instruments (Aagaard et al., 1997; Brander, 1999; Callaghan et al., 2004; Dette et al., 1995; MacMahan et al., 2005). Current meters deployed in cross shore or longshore transects provide Eulerian flow measurements and give insight in the temporal variations of rip currents. However, the installation of these instruments in the surf zone is problematic and this experimental set-up provides limited spatial information about flow patterns of rip currents. In more recent field studies GPS tracked drifters have been used to capture the flow pattern in a rip current more comprehensively and to overcome the limitations associated with fixed instrument transects (Austin et al., 2010; Johnson and Pattiaratchi, 2004; MacMahan et al., 2010). Observed flow patterns include symmetric and asymmetric rip current circulation cells as well as meandering alongshore currents (MacMahan et al., 2010). Several field studies suggest that the rip current is enhanced during low tide (Aagaard et al., 1997; Austin et al., 2010; Brander, 1999) because wave dissipation increases with lower water levels over the bar. The influence of the wave angle was studied numerically by Svendsen et al. (2000) who suggest that the strongest rips occur with normal incident waves because oblique incident waves generate longshore currents that possess enough inertia to bypass the channel. Voulgaris et al. (2011) also examined the velocities in a rip channel numerically and found a maximum with waves under an angle of $10^{\circ}$.

This study aims to improve the knowledge on rip currents on the Dutch coast. Specific attention is paid on wind sea conditions, oblique incidence and alongshore tidal currents that characterise this environment.

\section{FIELD STUDY}

\section{Methods and Conditions}

In August 2011 (yeardays 234 - 238), the SEAREX (Swimmer safety in Egmond aan Zee - A Rip current Experiment) experiment was conducted at Egmond aan Zee (Figure 2) which is located at the coast of North Holland (The Netherlands). The aim of the experiment was to obtain a data set of various nearshore flow patterns and drift velocities. This data was analysed to understand the characteristics of these flow patterns and their dependence on the present hydrodynamic conditions and the underlying bathymetry.

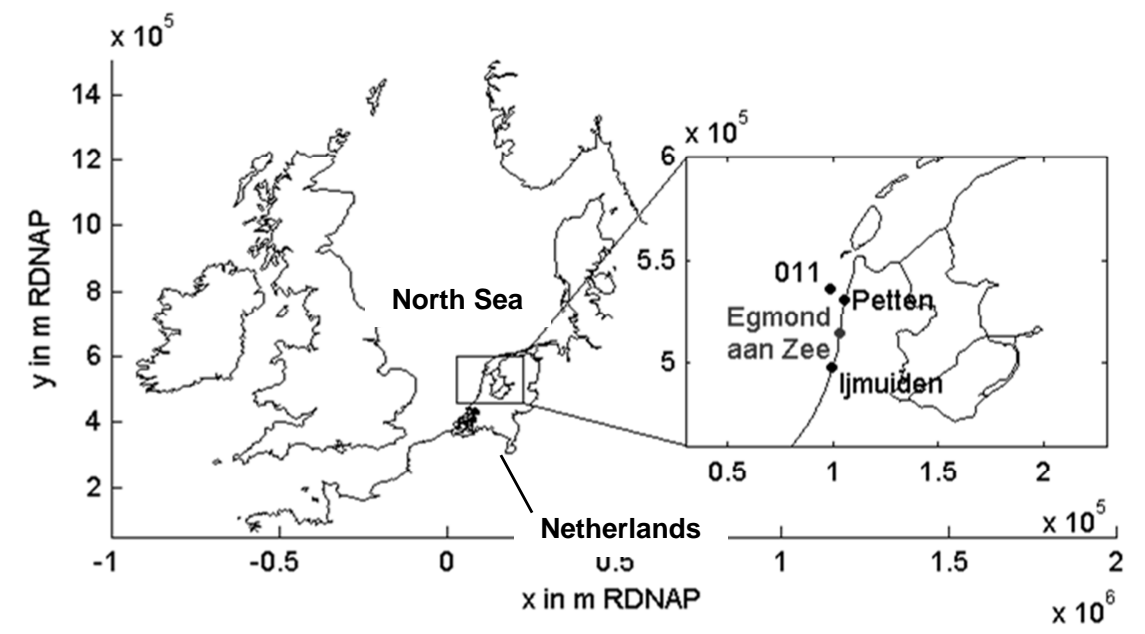

Figure 2 Location of the field site Egmond aan Zee and the directional waverider buoy (Instrument 011 ). RDNAP refers to the Dutch coordinate system 'Rijksdriehoek'.

Lagrangian velocities in the surf zone were measured with drifter instruments following the design described in MacMahan et al. (2009). Throughout the field experiment six measurement sessions were conducted under various wave, wind and tidal conditions, each consisting of four to five drifter deployments. Drifters were released simultaneously in the surf zone in sets of up to 12 drifters in arrays orientated either in alongshore or cross-shore direction to distinguish regions of different flow intensities. Drifters were retrieved when they either grounded on the bar or reached a stationary state of drifting shore parallel outside the surf zone.

Concurrently, a high resolution bathymetry survey was conducted. For the sub-tidal and inter-tidal area a personal water craft (PWC) (MacMahan, 2001) was used while the inter-tidal and super-tidal beach parts were surveyed with wheel-barrel mounted RTK-GPS. The survey showed the presence of three bars, an inter-tidal bar and an inner and outer sub-tidal bar. The bar of interest, the first sub-tidal bar, was located 220 to $240 \mathrm{~m}$ cross-shore (Figure 3) and was incised by two distinct rip channels at 
$280 \mathrm{~m}$ (Rip 1) and $80 \mathrm{~m}$ alongshore (Rip 2) in which the measurements were conducted. Between the two rip channels the bar tended to weld towards the beach indicating a transition to a higher beach state.

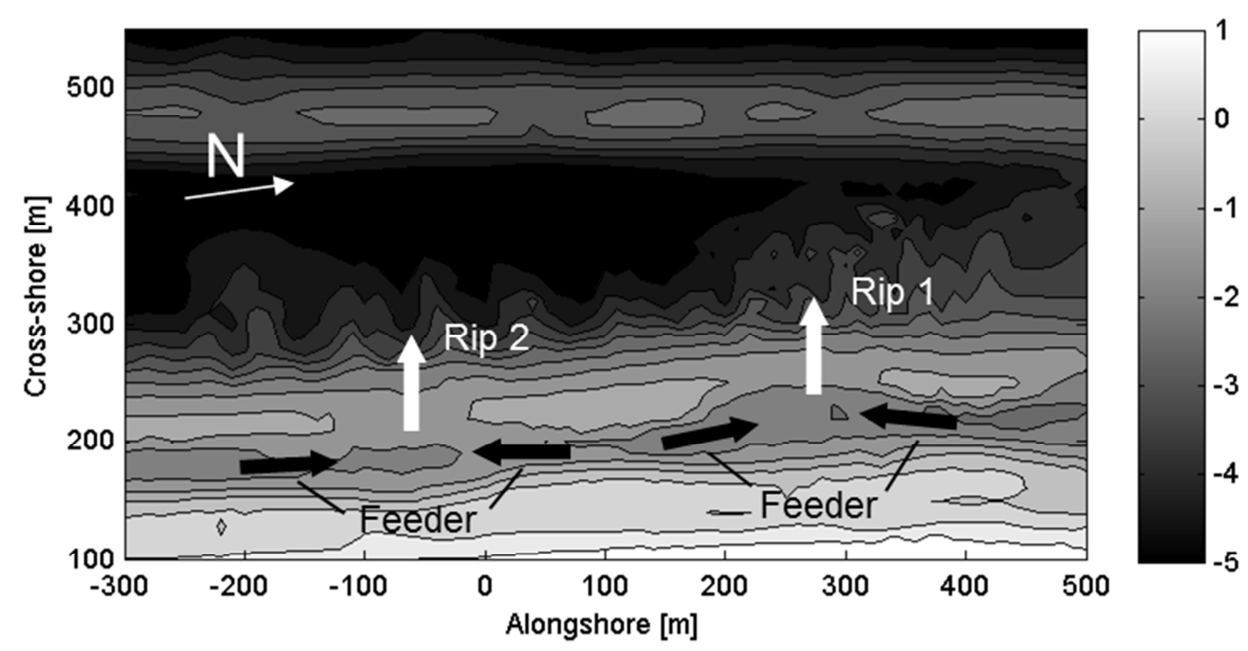

Figure 3 Surveyed bathymetry: The northern (Rip 1) and southern (Rip 2) rip channel are indicated.

The wave data was retrieved from a directional wave rider buoy that is installed $21 \mathrm{~km}$ North and $8.3 \mathrm{~km}$ offshore of the field site (Figure 2) at a water depth of $19.9 \mathrm{~m}$. Due to the alongshore uniformity of the North Holland coast the data was assumed to be representative for the field site. The wave conditions were moderate throughout the experiment with the offshore wave height $\mathrm{H}_{\mathrm{m} 0}$ ranging from 0.35 to $0.7 \mathrm{~m}$ and the wave period $\mathrm{T}_{\mathrm{m} 02}$ ranging from 2.4 to $3.8 \mathrm{~s}$. The wave angles varied between $9^{\circ}$ and more than $90^{\circ}$ (with respect to the shore normal).

\section{Observed flow pattern}

Rip currents were measured in a Lagrangian framework and were observed in 21 out of 28 drifter deployments. A rip event was defined as a flow pattern in which the drifters floated through the rip channel offshore.

In the experiment three flow patterns were observed: (1) a locally governed circulation cell (2) a pattern in which the drifter initially floats offshore and is then advected by the tidal longshore current and (3) a meandering longshore current between the shoreline and the first bar. Pattern (1) and (2) are rip events.

The local circulation cell (1) was always confined to the surf zone and was centred over the end of the downdrift bar (Figure 4) Only one circulation cell was observed downdrift of the channel while at no time during the experiment was a counter rotating eddy updrift of the rip channel observed. Drifters trapped in the circulation cell remained in the surf zone and floated shoreward over the bar again or stranded on the bar with sufficiently low water levels.

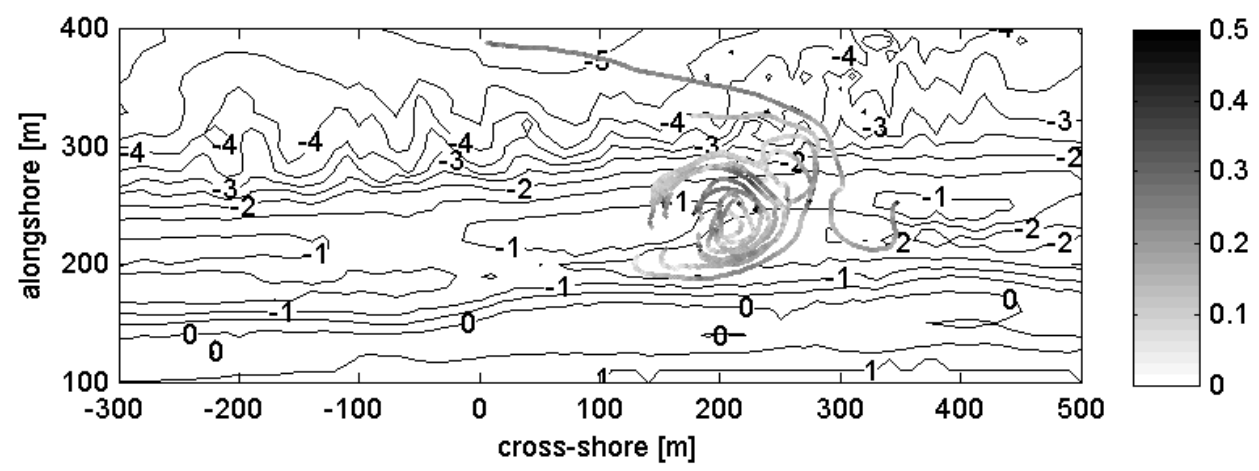

Figure 4 Local circulation cell (flow pattern 1) measured during the deployment on August 22, 5:00 pm (CET): The grey scale indicates drifter velocities in $\mathrm{m} / \mathrm{s}$ and the contour lines underneath represent the bathymetry.

In Pattern (2), the drifters floated through the channel, exited the surf zone and were drifting alongshore (Figure 5). The observed flow direction offshore of the bar was consistent with the tidal flow during those deployments. Flow pattern (2) was observed with rather high offshore flow velocities 
in the rip channel (on average udrifter $=0.31 \mathrm{~m} / \mathrm{s}$ compared to udrifter $=0.18 \mathrm{~m} / \mathrm{s}$ observed with flow pattern (1) and suggests that stronger currents possess enough inertia to enable the current (and the drifters) to exit the surf zone rather than forming a local circulation.

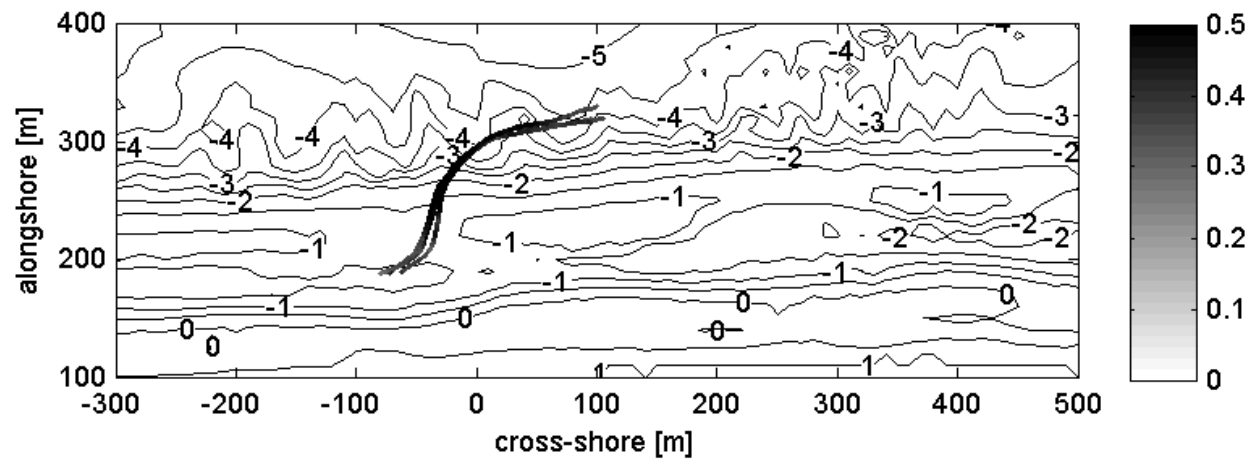

Figure 5 Offshore directed drifter paths (flow pattern 2) during the deployment on August 25, 10:40 am (CET): The greyscale indicates drifter velocities in $\mathrm{m} / \mathrm{s}$ and the contour lines underneath represent the bathymetry.

The meandering longshore current (flow pattern 3) is separated from pattern (2) in the way that drifter paths are confined to the zone between the breaker bar and the beach (Figure 6).

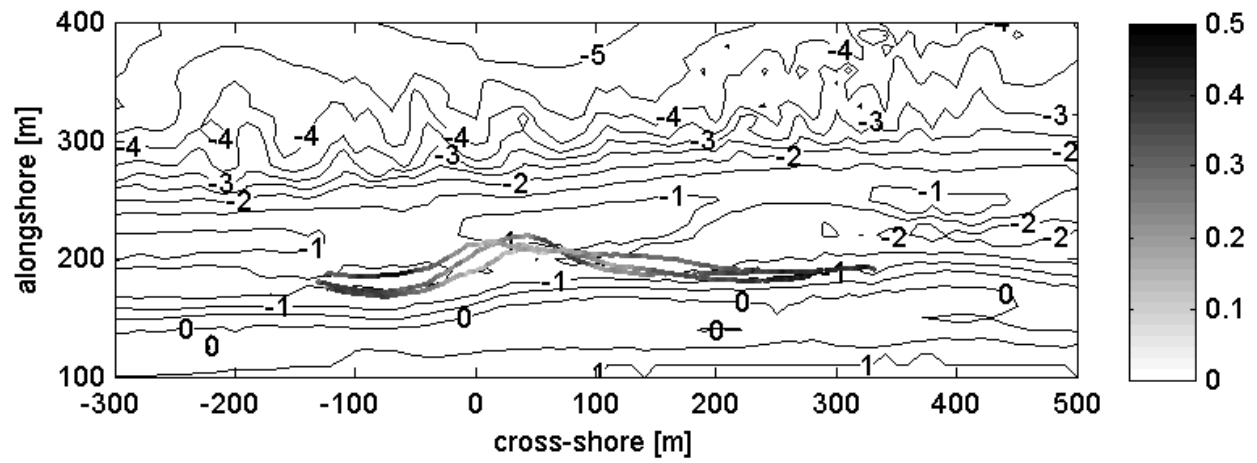

Figure 6 Meandering longshore current (flow pattern 3) during the deployment on August 25, 11:25 am (CET): The greyscale indicates drifter velocities in $\mathrm{m} / \mathrm{s}$ and the contour lines underneath represent the bathymetry.

This pattern was observed with water levels around or above NAP $+0 \mathrm{~m}$, where NAP is Dutch datum at about MSL. During all observations of flow pattern (3) tide, waves and wind acted together and favoured a northward drifter movement.

Maximum drifter velocities reached $0.60 \mathrm{~m} / \mathrm{s}$ and were measured on August 26 when also the highest offshore wave heights were recorded $\left(\mathrm{H}_{\mathrm{m} 0}=0.7 \mathrm{~m}\right)$. The offshore extent of the rip currents was on average $100 \mathrm{~m}$ offshore from the bar crest. During strong rip events, when drifters were ejected from the surf zone, the instruments floated as far as $150 \mathrm{~m}$ offshore while they remained within only 30 to $60 \mathrm{~m}$ from the bar crest when trapped in a circulation cell (Pattern 1).

\section{Flow velocities and offshore forcing}

In the following, the influence of wave height, water level and wave angle on rip current intensity is explored. The ratio of the offshore wave height $\mathrm{H}_{\mathrm{m} 0}$ over the water depth on the bar d indicates the intensity of wave breaking and the amount of wave dissipation while the wave angle denotes (together with the wave height) the strength of the wave-driven longshore current in the surf zone.

To quantify the rip events observed in the field a new variable is introduced, the rip strength. The rip strength is defined as the maximum offshore directed velocity component of the drifter in a rip event. To account for uncertainties associated with an individual drifter observation, the velocity maxima for each drifter within the deployment were averaged to determine the rip strength and the 90\% confidence intervals were estimated per deployment.

A statistically significant relationship $\left(\mathrm{R}^{2}=0.68\right.$ and $p$-value $\left.=0.048\right)$ between rip strength and the ratio of wave height over water depth $\mathrm{H}_{\mathrm{m} 0} / \mathrm{d}$ was identified (Figure 7 , left). This implies stronger rip activity with low water levels and high waves. Earlier studies suggested that the offshore velocity would decrease with increasing wave angle but such a trend was not observed in the field data which 
shows no trend (Figure 7, right). In contrast, the strongest rip was observed with $50^{\circ}$ angle of wave incidence offshore. This is, however, also the time period with the largest wave breaking ratio $\mathrm{H}_{\mathrm{m} 0} / \mathrm{d}$.

To address the effect of these parameters individually a numerical modelling study was performed, which is discussed next.
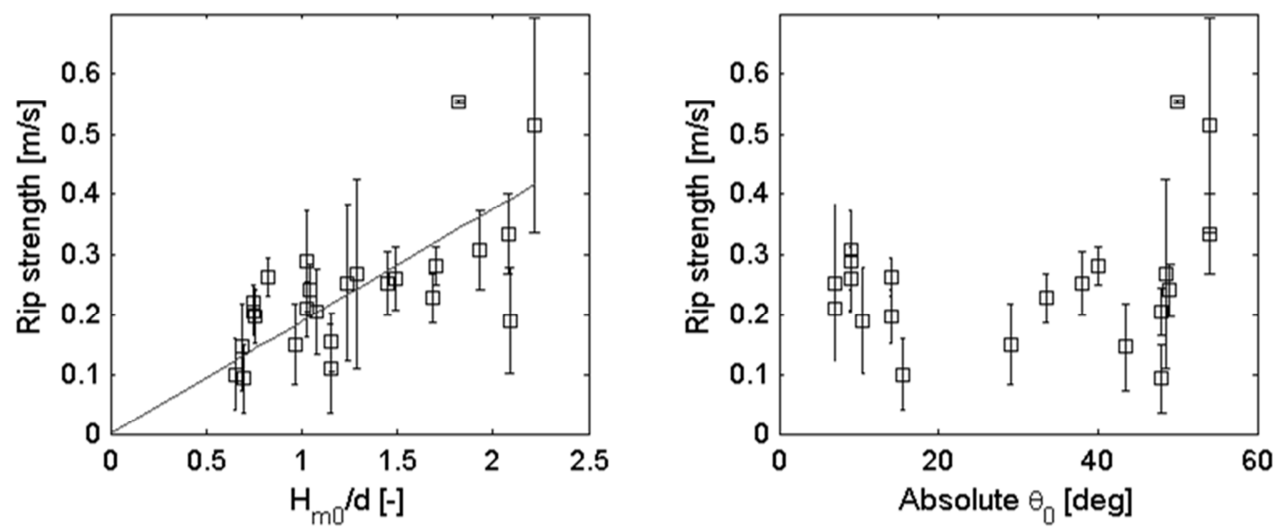

Figure 7 Rip strength versus $H_{m 0} / d$ (left) and absolute wave angle with the shore normal (right). Rip strength is defined as the maximum offshore velocity component of each drifter averaged per deployment. The error bars specify the $90 \%$ confidence interval of the average velocity per deployment. The solid line (left) is the linear least squares regression with $R^{2}=0.68$ and $p$-value $=0.0048$.

\section{NUMERICAL STUDY}

\section{Model Calibration and Validation}

A hindcast model of the measurements was built using XBeach (see Roelvink et al., 2009 for a model description) in instationary mode (with wave group forcing). Using the option of Lagrangianadvected numerical observation points (the so-called "drifter option" in XBeach), modelled flow pattern and rip current velocities were validated against observations. A sensitivity analysis of the grid resolution showed that the grid size must be as small as $10 \mathrm{~m}$ in the alongshore and $5 \mathrm{~m}$ in the crossshore direction in the nearshore zone to replicate the observations well. Wave dissipation was simulated according to Roelvink (1993) with a breaking parameter $\gamma$ equal to 0.55 . The tidal information was obtained from the Kuststrook model - a model of the Dutch coastal shelf that is nested into a global ocean model (Spee and Vatvani, 2009). Field observations of flow pattern (1) and (2) representing rip events were hindcasted using the above described settings (Figure 8).
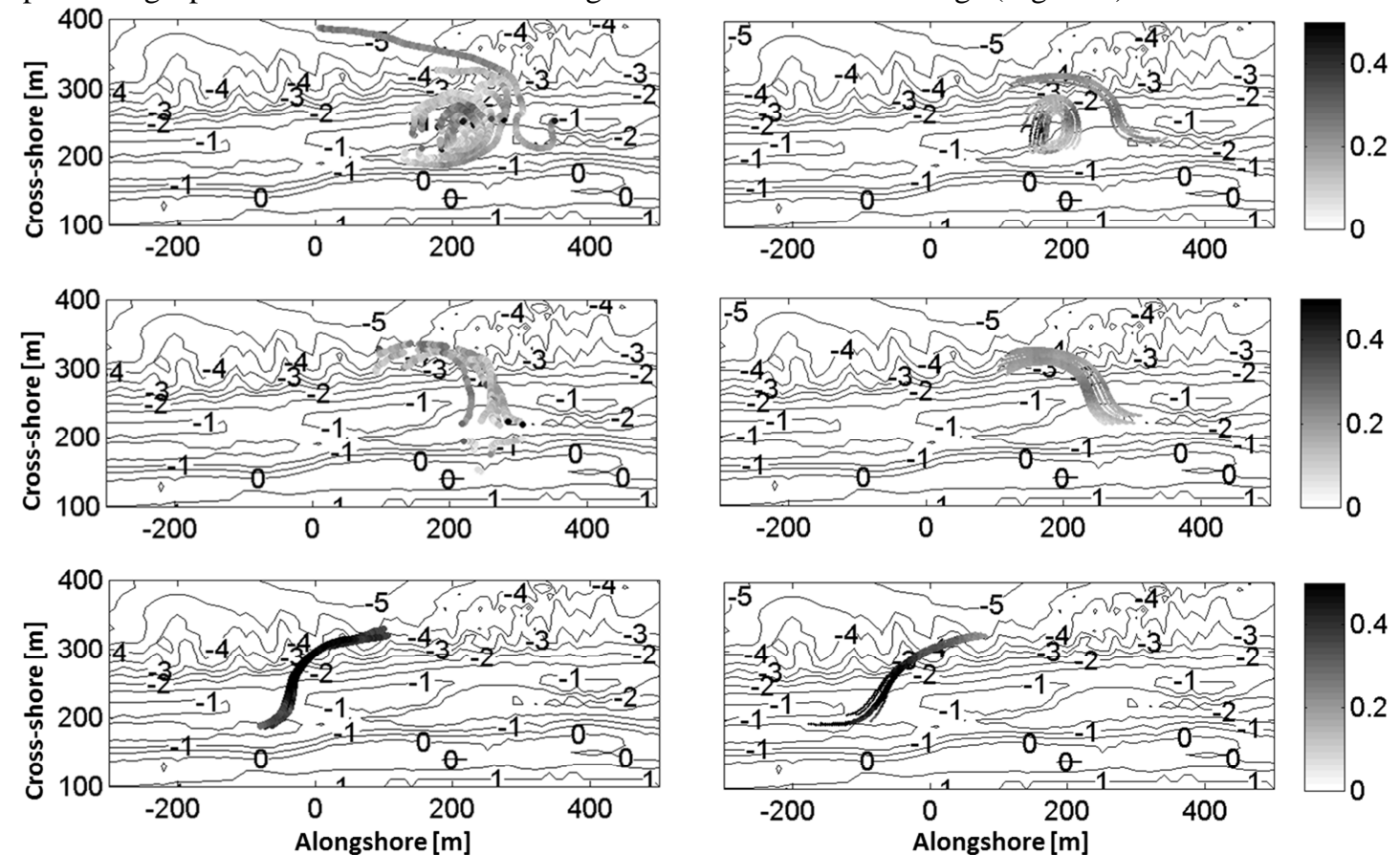

Figure 8 Left: Measured Drifter trajectories; Right: XBeach hindcast. From top to bottom: August 22, 5:00 pm. August 24, 5:40 pm. August 25, 10:40 am. (All in local time, CET) 
Overall, the field observations agreed very well with the numerical model results and this gives confidence to use this model in a sensitivity analysis of rip currents towards various parameters. However, it is noted that the model results did not compare favourably with the observations on August 25, 10:40 am, using the above described settings while they showed good correspondence if the breaking parameter $\gamma$ was increased to 0.8 . This may represent the effect of narrower frequency and directional spreading (and thus more swell-like wave conditions) or the effect of a cross-offshore wind during this deployment that may delay wave breaking (Douglass, 1990) and is subject to on-going research.

\section{Sensitivity of rip currents towards hydrodynamic and geometric parameters}

A sensitivity analysis was conducted with the aim to identify the hydrodynamic and geometric parameters that govern the initiation and mean properties of rip currents at Egmond aan Zee. During the field campaign rip currents were measured under a small range of conditions and consequently the observed rip current features could not be attributed unambiguously to specific parameters. Therefore, the validated model was used to test a broad range of hydrodynamic and geometric conditions and to examine the influence of the most prominent parameters independently.

The hydrodynamic parameters considered were wave height, wave period, wave angle, water level and tidal current. The default conditions consist of the wave height $\mathrm{H}_{\mathrm{m} 0}=0.5 \mathrm{~m}$, water level at NAP $0.3 \mathrm{~m}$ and normally incident waves. While the present wave conditions can be obtained from elaborated wave forecast models, the underlying bathymetry yields large uncertainties in modelling real time rip current conditions. The bathymetry can change at a time scale of weeks, days or even hours. The sensitivity of the model to geometrical features is therefore of high interest and this study focussed on the depth and width of the rip channel. The sensitivity analysis was performed on an idealised smooth and symmetric bathymetry as it was found that small scale bed irregularities $\mathrm{O}(0.5 \mathrm{~m})$ did not influence the rip current flow pattern and velocities.
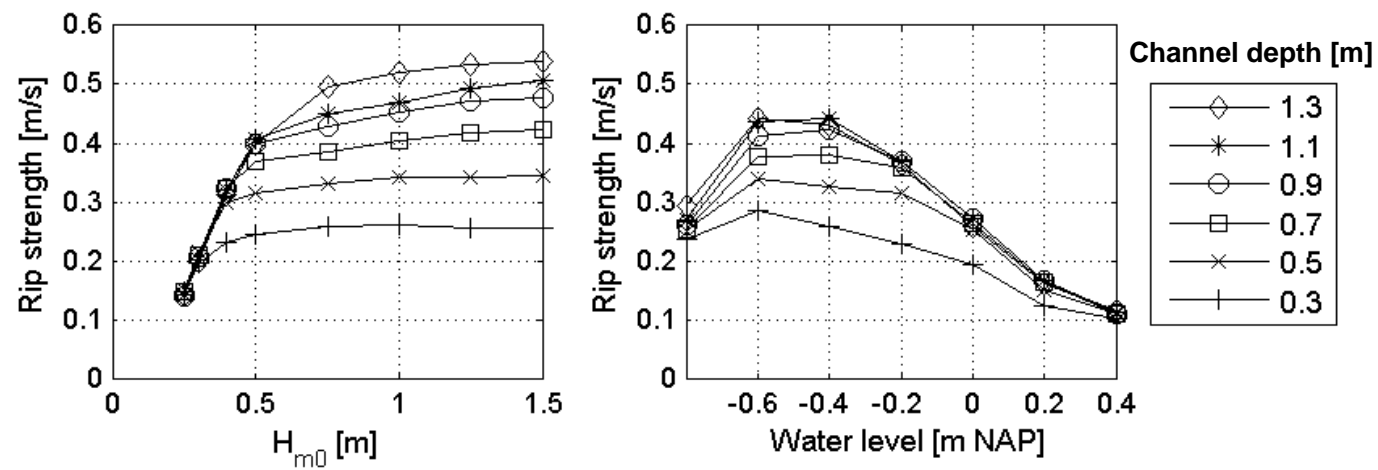

Figure 9 Rip strength vs. offshore wave height (left) and rip strength vs. water level (right) for various rip channel depths (see legend [m]). The rip channel depth is defined as the height difference between bar crest and rip channel trough.

The rip strength increases with increasing wave height; however, the results suggest that the rip strength reaches an upper limit which differs for various channel depths (Figure 9, left). The rip strength likewise increases with decreasing water level; but again the rip channel depth limits the maximum possible rip strength (Figure 9, right). Furthermore, the rip strength decreases with very low water levels below NAP - $0.6 \mathrm{~m}$ because the bar becomes partly emerged and hinders wave propagation over the bar.

The effect of the wave angle was found to depend on the rip channel width (Figure 10). The rip strength was not significantly affected by the wave angle for a site specific channel width $\mathrm{w}_{\mathrm{r}}=110 \mathrm{~m}$ as observed at Egmond an Zee. Even for very large wave angles $\left(327^{\circ} \mathrm{N}, 50^{\circ}\right.$ w.r.t. shore normal) the rip strength was not reduced significantly. However, for a narrow rip channel $\left(\mathrm{w}_{\mathrm{r}}=50 \mathrm{~m}\right)$, the wave angle had a significant negative influence on the rip strength. In a narrow channel strongest offshore velocities were produced with normally incident waves. 


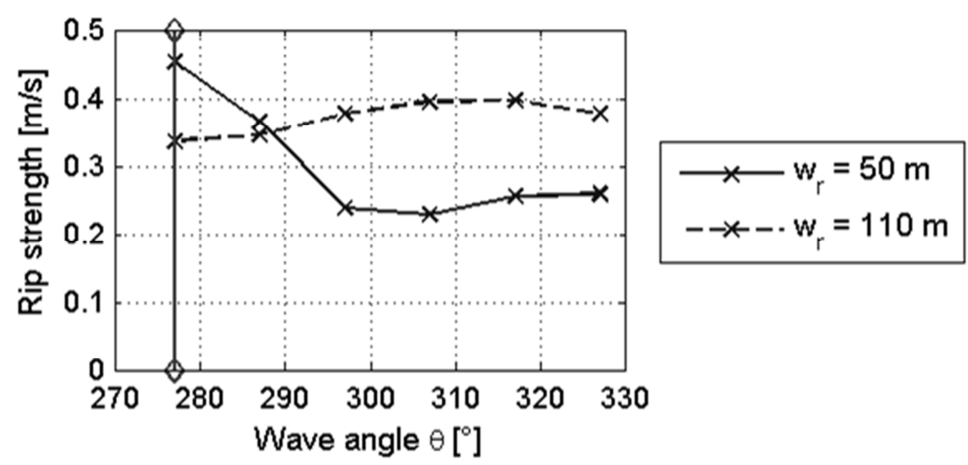

Figure 10 Rip strength vs. wave angle for a rip channel with $50 \mathrm{~m}$ width and with $110 \mathrm{~m}$ width. The latter corresponds to channel dimensions as observed at Egmond. The shore normal is $277^{\circ}$.

\section{DISCUSSION}

\section{Wave height, water level and bar height}

Video images (Argus) collected concurrent with the field experiment from the permanent Jan van Speijk lighthouse Argus station indicate that with higher water levels, the waves are not dissipated on the surf zone bar, but on the swash bar (Figure 11, bottom panel). This interrupts the driving mechanism for rip currents on the first surf zone bar and explains the low rip activity at times of low values of $\mathrm{H}_{\mathrm{m} 0} / \mathrm{d}$ during the field measurements. These observations are consistent with numerical model results.

However, as the model results show, the rip strength does not increase unbounded, but reaches an upper limit dependent on the rip channel depth. With large wave heights $\mathrm{H}_{\mathrm{m} 0}$ and a limited rip channel depth, wave breaking commences in the rip channel which induces radiation stress gradients and ultimately a water level set-up in the channel. If the wave height increases further, not only the water level set-up behind the bar will be larger, but also the one in the rip channel. Thus, the alongshore water level gradient that drives the rip current circulation does not increase any further.
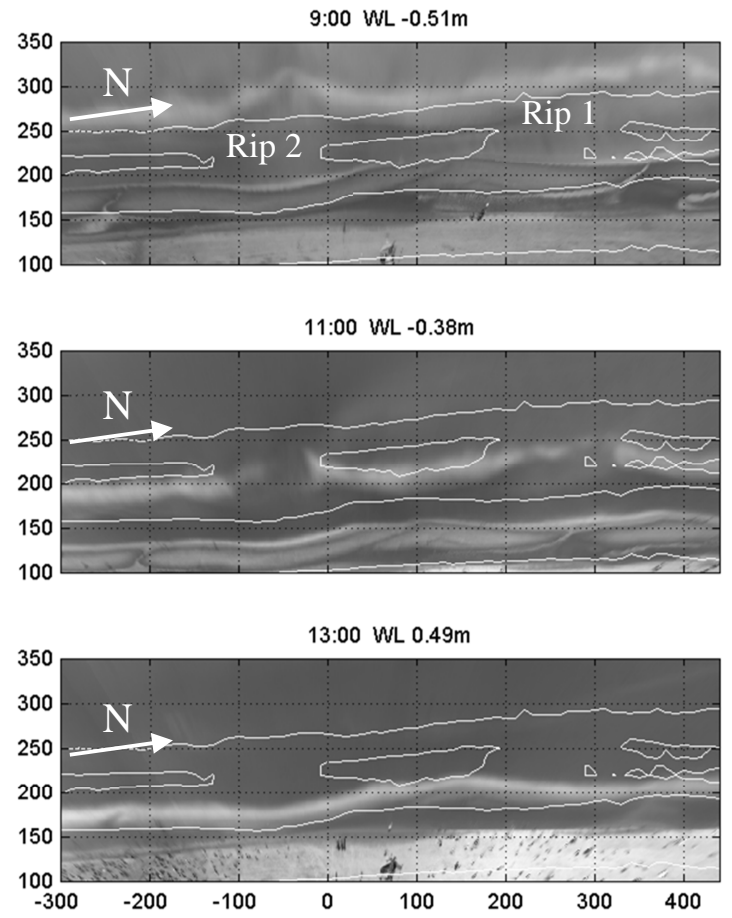

Figure 11 Series of Argus images on August 25. White bands in the images are a proxy for areas of predominant wave breaking. Top panel shows continuous wave breaking offshore of the bar - rip system around low tide. As water level rises (middle panel) no wave breaking is observed in the rip channel leaving a discontinuous wave breaking band. Around high tide (bottom panel) waves break inshore on the swash bar. 
Though the field data did not show clear evidence of this process, video derived images support the model results. At very low water levels, wave breaking commences in the channel (Figure 11, top panel). As a consequence the longshore variation in wave dissipation and water level set up (which drive the rip current circulation) are weakened (Rip 2) or completely absent (Rip 1). The offshore current in Rip 2 is evident from the protuberance in the wave dissipation band. The opposing current causes the waves to refract towards the current and causes a non-uniform wave dissipation band.

\section{Longshore currents}

The model predicts rip currents to cease with large wave angles in a narrow channel (Figure 10), which is consistent with previous numerical studies. Svendsen et al. (2000) argued that with large wave angles the longshore current possesses enough inertia to bypass the rip channel so that the circulation cells cannot be maintained anymore. However, the present study illustrates that for small wave heights the inertia of the longshore current is not sufficient to bypass wider channels and that drifters still float offshore even with large wave angles. An alongshore transect through the rip channel (Figure 12) shows that simulated alongshore velocities decrease in the channel because wave breaking, and thus the driving force of the wave-driven longshore current, is absent. In a wide rip channel, wave breaking is absent over a longer stretch and the longshore current vanishes completely or even changes direction as a result of the present rip circulation cell.

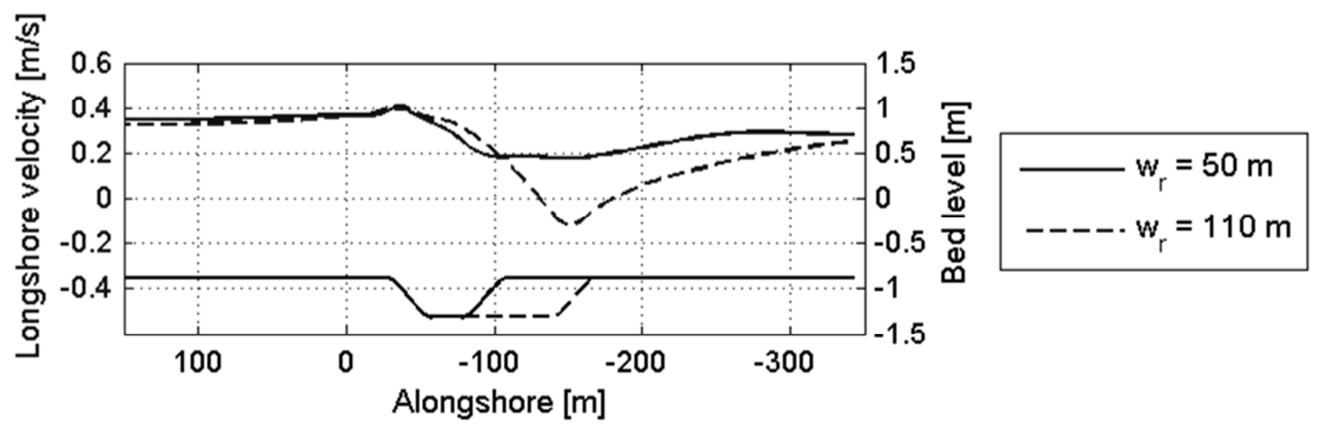

Figure 12 Alongshore transect of alongshore velocity on the (seaward flank of the bar)/(bar crest). Waves are obliquely incident resulting in an alongshore wave driven current. Solid line shows the model results for a narrow channel, dashed line shows the wide channel simulation.

The numerical model shows that rip currents are maintained in wide channels even with large wave angles and thus, explains the lack of correlation between rip current intensity and wave angle in the field (Figure 7, right). The rip channels at the field site were $110 \mathrm{~m}$ wide and thus relatively wide with respect to the wave forcing $\left(\mathrm{H}_{\mathrm{m} 0}=0.35\right.$ to $\left.0.7 \mathrm{~m}\right)$.

Outside the surf zone long shore currents are dominated by the tide and not by the incoming waves. Once the drifters have exited the surf zone they are subjected to the tidal current. Thus, the orientation of the rip current outside of the surf zone oscillates with the tidal cycle.

\section{CONCLUSIONS}

A field experiment demonstrated the existence of rip currents at the Dutch coast where, under moderate wave conditions $\left(H_{m 0}=0.35\right.$ to $\left.0.7 \mathrm{~m}\right)$, these currents reached a considerable strength of up to $0.6 \mathrm{~m} / \mathrm{s}$. Three flow patterns were observed: (1) local one-sided circulation cell that was observed with rather weak rip current flow, (2) strong offshore movement of the drifters that were then advected by a longshore current offshore of the bar (observed with rather strong rips), (3) a meandering longshore current that prevailed with high water levels. The offshore velocities in the rip current increased with increasing ratio of offshore wave height over water depth on the bar while the wave angle did not affect the offshore velocities.

The 2D hydrostatic model XBeach was used with in-stationary wave forcing to hindcast the field experiments. The model was able to replicate the observed flow pattern and velocities well and was therefore used to investigate rip current behaviour under a wider range of conditions.

Field observations and numerical modelling show that the strength of a rip current increases with increasing wave height and decreasing water level. However, the maximum possible offshore velocities are limited by the rip channel depth because the alongshore water level gradient that drives the rip current does not increase once wave breaking has commenced in the rip channel. The wave angle does not influence the strength of the rip current for typical rip channel widths and wave heights observed during the field experiment. The numerical study showed that the wave-induced longshore current does 
not possess enough inertia to bypass wide channels (relative to the strength of the wave-driven current and thus to wave height and wave angle). Only in a relatively narrow rip channels a large wave angle has a negative impact on the rip strength. Longshore currents generated by the tide dominate outside the surf zone and govern the orientation of the rip current offshore of the bar.

\section{ACKNOWLEDGMENTS}

We thank the many volunteers who assisted in collecting the field data: Andrew Pomeroy, Antoon Hendriks, Arnold van Rooijen, Brice Blossier, Claire Bouchigny, Cilia Swinkels, Dano Roelvink, Dirk Knipping, Erwin Bergsma, Giorgio Santinelli, Greta van Velzen, Hesseltje Roelvink, Ivan Garcia, Jamie Lescinski, Jeroen Stark, Lisa de Graaf, Leo Sembiring, Maarten van Ormondt, Roland Vlijm, Timon Pekkeriet and in particular Willem Verbeek whose experience with rip currents at Egmond aan Zee was valued highly. We appreciate the help and equipment provided by Shore Monitoring and the bathymetry survey that was conducted by them. On site Shore Monitoring was represented by Roeland de Zeeuw and Sierd de Vries. Rijkswaterstaat is gratefully acknowledged for the use of the wave buoy data taken at Petten that was provided to us by Andre Jansen. The research was funded by Flood Control 2015 (Realtime Safety on Sedimentary Coasts program) and Building with Nature (Swimmer Safety project), Deltares Strategic Funding in the framework of the System Tools for Prevention and Preparation program (project 1202362). M.A. de Schipper was funded by Building with Nature under project code NTW 3.2. The Building with Nature program is funded from several sources, including the Subsidieregeling Innovatieketen Water (SIW, Staatscourant nrs 953 and 17009) sponsored by the Dutch Ministry of Transport, Public Works and Water Management and partner contributions of the participants to the Foundation EcoShape. The program receives co-funding from the European Fund for Regional Development EFRO and the Municipality of Dordrecht.

\section{REFERENCES}

Aagaard, T., Greenwood, B., and Nielsen, J. 1997. Mean currents and sediment transport in a rip channel, Marine Geology, 140(1-2), 25-45.

Austin, M., Scott, T. M., Brown, J. W., Brown, J. A., MacMahan, J. H., Masselink, G., and Russell, P. 2010. Temporal observations of rip current circulation on a macro-tidal beach, Continental Shelf Research, 30, 1149-1165.

Austin, M. J., Scott, T. M., Brown, J. W., Brown, J. A., and MacMahan, J. H. 2009. Macrotidal rip current experiment: circulation and dynamics, Journal of Coastal Research, SI 56, 24-28.

Bowen, A. 1969. Rip Currents 1. Theoretical Investigations J. Geophys. Res., 74(23), 5467-5478.

Brander, R. W. 1999. Field observations on the morphodynamic evolution of a low-energy rip current system, Marine Geology, 157(3-4), 199-217.

Brander, R. W., and Short, A. D. 2000. Morphodynamics of a large-scale rip current system at Muriwai Beach, New Zealand, Marine Geology, 165(Compendex), 27-39.

Brander, R. W., and MacMahan, J. H. 2011. Future Challenges for Rip Current Research and Outreach, in Rip Currents: Beach Safety, Physical Oceanography and Wave Modeling, edited by S. Leatherman and J. Fletemeyer, CRC Press, Boca Raton, FL.

Bruneau, N., Castelle, B., Bonneton, P., Pedreros, R., Almar, R., Bonneton, N., Bretel, P., Parisot, J.-P., and Sénéchal, N. 2009. Field observations of an evolving rip current on a meso-macrotidal welldeveloped inner bar and rip morphology, Continental Shelf Research, 29(14), 1650-1662.

Callaghan, D. P., Baldock, T. E., and Nielsen, P. 2004. Pulsing and Circulation in Rip Current System, in International Conference Coastal Engineering, edited by J. M. Smith, pp. 1493-1505, American Society of Civil Engineers, Lisbon.

Dalrymple, R. A., MacMahan, J. H., Reniers, A. J. H. M., and Nelko, V. 2011. Rip Currents, Annual Review of Fluid Mechanics, 43(1), 551-581.

Dette, H. H., Peters, K., and Spignat, F. 1995. About rip currents at a meso-tidal coast, in Coastal Dynamics '95, edited, pp. 477-488, American Society of Civil Engineers, Gdansk, Poland.

Douglass, S. 1990. Influence of wind on breaking waves, Journal of Waterway, Port, Coastal, and Ocean Engineering, 116(6).

Johnson, D., and Pattiaratchi, C. 2004. Transient rip currents and nearshore circulation on a swelldominated beach, J. Geophys. Res., 109(C2), C02026.

Longuet-Higgins, M. S., and Stewart, R. w. 1964. Radiation stresses in water waves; a physical discussion, with applications, Deep Sea Research and Oceanographic Abstracts, 11(4), 529-562.

MacMahan, J. H. 2001. Hydrographic surveying from a personal watercraft, Journal of Surveying Engineering, 127(1). 
MacMahan, J. H., Brown, J., and Thornton, E. 2009. Low-Cost Handheld Global Positioning System for Measuring Surf-Zone Currents, Journal of Coastal Research, 25(3), 744-754.

MacMahan, J. H., Thornton, E. B., Stanton, T. P., and Reniers, A. J. H. M. 2005. RIPEX: Observations of a rip current system, Marine Geology, 218(Compendex), 113-134.

MacMahan, J. H., et al. 2010. Mean Lagrangian flow behavior on an open coast rip-channeled beach: A new perspective, Marine Geology, 268(1-4), 1-15.

Roelvink, D., Reniers, A., van Dongeren, A., van Thiel de Vries, J., McCall, R., and Lescinski, J. 2009. Modelling storm impacts on beaches, dunes and barrier islands, Coastal Engineering, 56(11-12), 1133-1152.

Spee, E., and Vatvani, D. (2009), Evaluatie van de nieuwe bodem V61-04 voor het Kuststrookmodel, Deltares Rep. 1200103-023, Deltares, Delft.

Svendsen, I. A., Haas, K. A., and Zhao, Q. 2000. Analysis of Rip Current Systems, in 29th International Conference on Coastal Engineering, edited by B. L. Edge, pp. 1127-1140, American Society of Civil Engineers, Sydney.

Voulgaris, G., Kumar, N., and Warner, J. C. 2011. Methodology for Prediction of Rip Currents Using a Three-Dimensional Numerical, Coupled, Wave Current Model, in Rip Currents: Beach Safety, Physical Oceanography and Wave Modeling, edited by S. Leatherman and J. Fletemeyer, CRC Press, Boca Raton, FL. 